\title{
Analisa Persespsi Masyarakat Pendatang Terhadap Kearifan Lokal Metode Fuzzy Inference System (FIS) Mamdani
}

\author{
Silky Safira ${ }^{1}$, Wifra Safitri ${ }^{2}$ \\ ${ }^{1}$ Universitas Putra Indonesia "YPTK" Padang, Indonesia \\ ${ }^{2}$ Universitas Putra Indonesia "YPTK" Padang, Indonesia \\ Email : Silkysafira1@gmail.com
}

\begin{abstract}
Fuzzy logic is considered capable of mapping input into output without ignoring existing factors. Fuzzy logic is very flexible and tolerant of existing data. By using fuzzy logic, a model will be produced from a system that is able to estimate the perceptions of immigrants to local wisdom. The factors that influence the determination of immigrants perceptions of local wisdom with fuzzy logic are the attitude of immigrant communities. Society's socio-cultural life is shown by the many links to other social life, such as ideology, lifestyle, and economy. This means that changes in one socio-cultural life will affect other social and cultural lives. Therefore this system is made so that the public can know, study and examine the variety of local wisdom, examine the role of indigenous and immigrant people in preserving local wisdom and study the strategies of indigenous and immigrant populations in limiting conflict and so on by applying fuzzy mamdani methods that are expected to provide decisions good in responding to the perceptions of immigrants towards local wisdom in West Kinali Pasaman.
\end{abstract}

Keywords: Fuzzy Logic, Mandani, Local wisdom, Perception ,Cummunity

\begin{abstract}
Abstrak
Logika fuzzy dianggap mampu untuk memetakan suatu input kedalam suatu output tanpa mengabaikan faktor - faktor yang ada. Logika fuzzy sangat fleksibel dan memiliki toleransi terhadap data-data yang ada. Dengan menggunakan logika fuzzy, akan dihasilkan suatu model dari suatu sistem yang mampu memperkirakan bagaimana persepsi masyarakat pendatang terhadap kearifan lokal. Faktor - faktor yang mempengaruhi dalam menentukan persepsi masyarakat pendatang terhadap kearifan lokal dengan logika fuzzy salah satunya adalah Sikap masyarakat pendatang. Kehidupan sosial budaya masyarakat ditunjukkan dengan banyaknya kaitan terhadap kehidupan sosial lainnya, seperti ideologi, pola hidup, dan ekonomi. Ini berarti perubahan kehidupan sosial budaya yang satu akan berpengaruh terhadap kehidupan social budaya yang lain. Sistem ini dibuat agar masyarakat dapat mengetahui, mempelajari serta megkaji ragam kearifan local, mengkaji peran penduduk pribumi dan pendatang dalam melestarikan kearifan lokal dan mengkaji stategi penduduk pribumi dan pendatang dalam membatasi konflik dan lain sebagainya dengan menerapkan metode fuzzy mamdani diharapkan dapat memberikan keputusan yang baik dalam menanggapi persepsi masyarakat pendatang terhadap kearifan lokal Di Kinali Pasaman Barat.
\end{abstract}

Kata Kunci: Fuzzy Logic, Mamdani, Kearifan Lokal, Persepsi, Masyarakat

\section{Pendahuluan}

Logika fuzzy adalah salah satu cabang dari AI (Artificial Intelligence). Logika fuzzy alat matematika yang memungkinkan modem komputer digital untuk model sistem yang didefinisikan dengan tepat. Pada [1] membahas tentang memprediksi curah hujan dengan fuzzy logic. Dimana akan dilakukan proses matching dan pengkelasan data. Hasil prediksi, menunjukkan akurasi sebesar $82,19 \%$ Target data disesuaikan menjadi 5 kategori yaitu cerah, hujan ringan, hujan sedang, hujan lebat dan badai berdasarkan standar BMKG.Sedangkan dalam penelitian ini, Sistem Inferensi Fuzzy dengan Metode Tsukamoto dapat memprediksi Tingkat Kompetensi Profesional Pendidik dengan memasukan komponen atau skor dari kompetensi professional pendidik [2]. Logika fuzzy diyakini sangat fleksibel dan memiliki toleransi terhadap data-data yang ada. Dengan menggunakan logika fuzzy, akan dihasilkan. suatu model dari suatu sistem yang mampu memperkirakan bagaimana persepsi masyarakat pendatang terhadap kearifan local.

Submitted : 18 Agustus 30, 2019 Accepted : 17 November 2019 Published : 1 December 2019

DOI : 10.35134/komtekinfo.v6i2.907 
Persepsi pendatang baru terhadap kearifan local dalam perkembangannya masyarakat melakukan adaptasi terhadap lingkungannya dengan mengembangkan suatu kearifan yang berwujud pengetahuan atau ide, peralatan, dipadu dengan norma adat, nilai budaya, aktivitas mengelola lingkungan guna mencukupi kebutuhan hidupnya. Pada saat ini, penduduk Nagari Kinali bersifat heterogen bila ditinjau dari latar belakang etnik budaya. Ada tiga asal usul etnik utama yang menempati daerah ini, yakni Minang, Jawa dan Batak/Mandailing. Dilihat dari beragamnya budaya penduduk Nagari Kinali, perlu diperhatikannya pemahaman tentang kearifan lokal pada masyarakat agar tidak terjadi persinggungan antar etnis/ suku masyarakat yang banyak terjadi. Oleh karena itu, diyakini bahwa pemahaman tentang kearifan lokal pada masyarakat dapat mengharmonisasikan kehidupan masyarakat multi-etnik yang ada dan meminimalisir konflik. Proses pengintegrasian masyarakat multi etnik di Menggala dengan merujuk pada pemahaman kearifan lokal penduduk Nagari Kinali. Tujuannya mengetahui, mempelajari dan mengkaji peran penduduk pendatang dan pribumi dalam

melestarikan kearifan lokal, dalam membatasi konflik serta menguji suatu metode prediksi yang dapat menggambarkan persepsi persepsi kearifan lokal berdasarkan faktor - faktor yang mempengaruhinya dengan meggunakan fuzzy Mamdani.

\section{Tinjauan Literatur}

Penelitian ini diawali dengan mengidentifikasi masalah yakni menggunakan metode fuzzy mamdani yang membantu memberikan ketetapan kriteria dan menggambarkan persepsi kearifan lokal berdasarkan faktorfaktor yang mempengaruhinya. Tujuan penelitian yakni menentukan persepi pendatang terhadap kearifan pendatang dengan menggunakan Fuzzy Mamdani. Pada tahap berikutnya yakni pengumpulan data dilakukan dengan observasi secara langsung.

\subsection{Analisa Data}

Dalam menentukan persepsi masyarakat pendatang terhadap kearifan lokal ada beberapa aspek yang sangat mempengaruhi yaitu dari tingkat pemahaman adat setempat, pengalaman melaksanakan adat setempat dan aspek sikap masyarakat terhadap budaya setempat. Dari beberapa data dan aspek yang telah dikumpulkan akan dilakukan analisa sehingga data tersebut akan dikelompokan menjadi himpunan fuzzy yang bisa diolah menggunakan sistem fuzzy Mamdani. Sebelum dibangun fuzzy inference nya terlebih dahulu data yang ada dinormalisasikan kedalam satu nilai pada table 1 .

Table 1: Data Masyarakat Kinali - Pasaman Barat

\begin{tabular}{|c|c|c|c|c|c|c|c|c|}
\hline \multirow[t]{2}{*}{ No } & \multirow[t]{2}{*}{ Nama } & \multirow{2}{*}{$\begin{array}{c}\text { Umur( } \\
\text { th) }\end{array}$} & \multirow[t]{2}{*}{ JK } & \multirow[t]{2}{*}{ Alamat } & \multirow[t]{2}{*}{ Pekerjaan } & \multicolumn{3}{|c|}{ Aspek yang Diamati } \\
\hline & & & & & & $\mathbf{A}$ & B & $\mathrm{C}$ \\
\hline 1 & Sabani & 60 & $\mathrm{~L}$ & Alamanda & Buruh & 20 & 50 & 70 \\
\hline 2 & Nursiah & 62 & $\mathrm{P}$ & Sungai Balai & $\begin{array}{l}\text { Pensiunan } \\
\text { Guru }\end{array}$ & 40 & 60 & 80 \\
\hline 3 & Sulastri & 40 & $\mathrm{P}$ & Kp Cubadak & Pedagang & 70 & 70 & 80 \\
\hline 4 & Isniyah & 45 & $P$ & $\begin{array}{l}\text { Kampung } \\
\text { Cubadak }\end{array}$ & Pedagang & 75 & 75 & 80 \\
\hline 5 & $\begin{array}{l}\text { Erna } \\
\text { Puspita }\end{array}$ & 35 & $\mathrm{P}$ & $\begin{array}{l}\text { Kampung } \\
\text { Cubadak }\end{array}$ & Ibu RT & 80 & 70 & 50 \\
\hline 6 & Suarni & 60 & $\bar{P}$ & Sungai Balai & Tani & 90 & 80 & 40 \\
\hline 7 & Supriadi & 20 & $\bar{L}$ & $\begin{array}{l}\text { Kampung } \\
\text { Cubadak }\end{array}$ & Guru & 90 & 85 & 85 \\
\hline 8 & Martias & 52 & $\mathrm{~L}$ & Lubuk Karak & Pedagang & 80 & 80 & 80 \\
\hline 9 & Ernis & 40 & $\mathrm{P}$ & Lubuk Karak & Bidan & 70 & 80 & 86 \\
\hline 10 & Karnida & 45 & $\mathrm{P}$ & Lubuk Anau & Bidan & 70 & 75 & 80 \\
\hline
\end{tabular}




\section{Metodologi}

Penelitian ini diawali dengan mengidentifikasi masalah yakni menggunakan metode fuzzymamdani yang membantu memberikan ketetapan kriteria dan menggambarkan persepsi kearifan lokal berdasarkan faktorfaktor yang mempengaruhinya. Tujuan penelitian yakni menentukan persepi pendatang terhadap kearifan pendatang dengan menggunakan Fuzzy Mamdani.Pada tahap berikutnya yakni pengumpulan data dilakukan dengan observasi secara langsung. Dapat dilihat pada gambar 1.

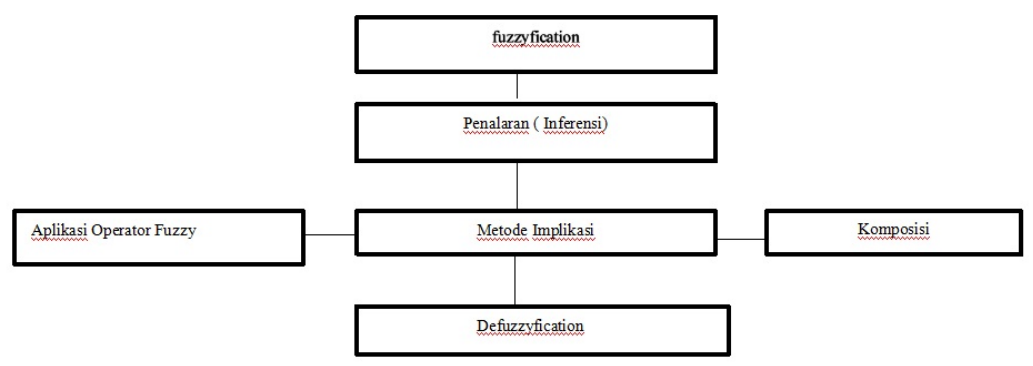

Gambar 1 Kerangka Penelitian

Pembahasan ini berisi penjelasan tentang kerangka kerja penelitian berdasarkan gambar 1 yaitu Ada 3 variabel utama untuk input dan 1 variabel output untuk menentukan persepsi masyarakat pendatang terhadap kearifan lokal. Pemahaman Adat Setempat, Pengalaman Melaksanakan Adat Setempat, Masyarakat Terhadap Budaya Setempat. Sebagai output yaitu Persepsi Masyarakat Pendatang Terhadap Kearifan Lokal.Tahap dari proses perhitungan fuzzy berikutnya adalah tahapan penalaran. Dalam proses penalaran ada 3 hal yang dilakukan yaitu mengaplikasi operator fuzzy, metode implikasi dan komposisi. Langkah terakhir dalam proses ini adalah defuzzifikasi atau disebut juga tahapan di mana besaran fuzzy dari sistem inferensi, diubah ke besaran tegas.

\section{Hasil dan Diskusi}

Dalam menentukan persepsi masyarakat pendatang terhadap kearifan lokal ada beberapa aspek yang sangat mempengaruhi yaitu dari tingkat pemahaman adat setempat, pengalaman melaksanakan adat setempat dan aspek sikap masyarakat terhadap budaya setempat. Dari beberapa data dan aspek yang telah dikumpulkan akan dilakukan analisa sehingga data tersebut akan dikelompokan menjadi himpunan fuzzy yang bisa diolah menggunakan sistem fuzzy Mamdani.

\subsection{Pengolahan Data dan Analisa Fuzzy}

Tahap ini diawali dengan menetapkan variable-variabel input yang akan digunakan untuk menentukan persepsi masyarakat pendatang terhadap kearifan local sebagai outputnya pada gambar 2 .

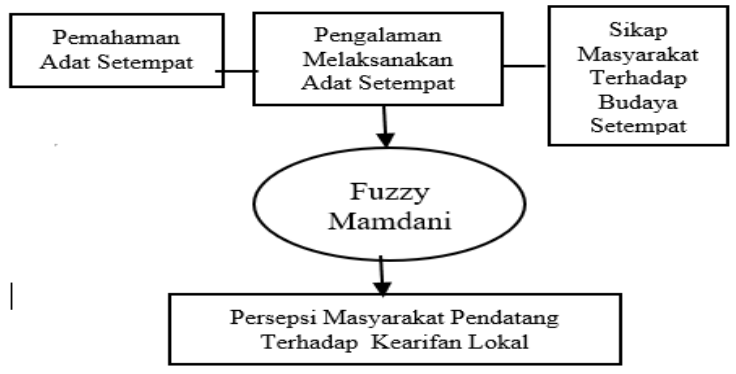

Gambar 2 Analisa Fuzzy 


\subsection{Fuzzy fication}

Ada 3 variabel utama untuk input dan 1 variabel output untuk menentukan persepsi masyarakat pendatang terhadap kearifan local yaitu terdiri dari Pemahaman Adat Setempat, Pengalaman Melaksanakan AdatSetempat, Masyarakat Terhadap Budaya Setempat sebagai ouputnya yaitu Persepsi Masyrakat Pendatang Terhadap Kearifan Lokal pada table 2.

Tabel 2. Semesta Pembicaraan

\begin{tabular}{lll}
\hline \multirow{2}{*}{ Fungsi } & Nama Variabel & $\begin{array}{l}\text { Semesta } \\
\text { Pembicaraan }\end{array}$ \\
\hline \multirow{4}{*}{ Input } & Pemahaman Adat Setempat & {$[20-90]$} \\
\cline { 2 - 3 } & Pengalaman Melaksanakan Adat & {$[10-80]$} \\
& Setempat & \\
\cline { 2 - 3 } & Sikap Masyarakat Terhadap Budaya & {$[10-75]$} \\
\hline Output & Setempat & \\
& Persepsi Masyarakat Pendatang & {$[10-90]$} \\
& Terhadap Kearifan Lokal & \\
\hline
\end{tabular}

Variable persepsi masyarakat pendatang terhadap kearifan local mempunyai nilai yang dinyatakan dengan kondisi kurang, sedang, dan baik.Masing - masing kondisi mempunyai rentang nilai yang ditetapkan tersebut dari nilai terendah10 sampai nilai tertinggi dari 90. Himpunan fuzzy untuk output pada tabel 3.

Tabel 3. Persepsi Masyarakat Pendatang Terhadap Kearifan Lokal untuk Output

\begin{tabular}{llll}
$\begin{array}{l}\text { Nama variabel } \\
\text { fuzzy }\end{array}$ & $\begin{array}{l}\text { Model } \\
\text { MF }\end{array}$ & $\begin{array}{l}\text { Variabel } \\
\text { Himpunan }\end{array}$ & Range \\
\hline $\begin{array}{l}\text { Sikap } \\
\text { Masyarakat }\end{array}$ & Trapmf & Kurang & $10-50$ \\
$\begin{array}{l}\text { Terhadap } \\
\text { Budaya }\end{array}$ & Trimf & Sedang & $30-70$ \\
Setempat & Trapmf & Baik & $50-90$ \\
\hline
\end{tabular}

Dimana : MF = Membership Function

Diagram membership function untuk output persepsi masyarakat pendatang terhadap kearifan local pada gambar 3 .

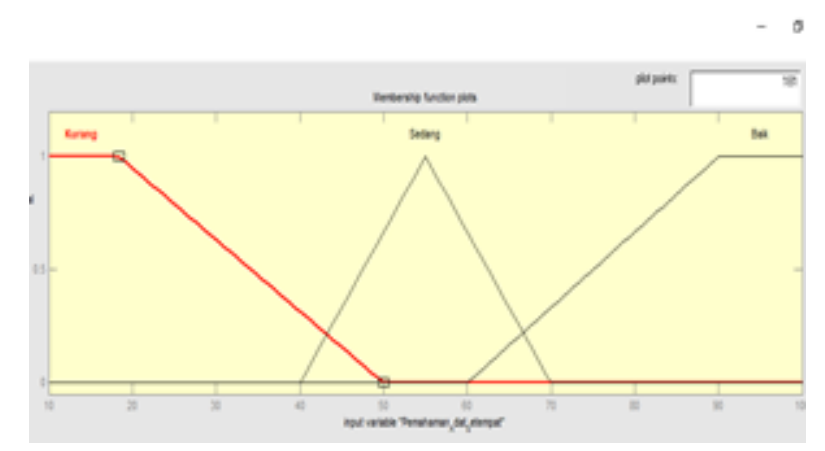

Gambar 3.Membership Function Variabel Persepsi Masyarakat Pendatang Terhadap Kearifan Lokal 


\subsection{Penggolahan Data Dengan Fuzzy}

Input:

Nama : Nimar

Pemahaman Adat Setempat $=40$

Pengalaman Melaksanakan Adat Setempat $=55$

Sikap Masyarakat Terhadap Budaya Setempat $=30$.

Pemahaman Adat Setempat 40 termasuk kedalam himpunan fuzzy sedang maka tingkat keanggotaan sesuai fungsi :

Himpunan Fuzzy Pemahaman Adat Setempat kurang (40) $=50-40 / 50-20=10 / 30=0,33$

Nilai 40 termasuk dalam range Pemahaman Adat Setempat kurang, maka hasil yang didapat adalah 0,33.

Himpunan Fuzzy Pemahaman Adat Setempat sedang $(40)=70-40 / 70-40=1$

Nilai 40 merupakan termasuk dalam range Pemahaman Adat Setempat sedang, maka hasil yang didapat adalah 1 .

Himpunan Fuzzy Pemahaman Adat Setempat baik (40) $=0,0$

Nilai 40 tidak termasuk dalam range Pemahaman Adat Setempat baik.

Variabel Pengalaman Melaksanakan Adat Setempat telah didefinisikan pada tiga himpuan fuzzy, yaitu: kurang, sedang dan baik.

Pengalaman Melaksanakan Adat Setempat 55 termasuk kedalam himpunan fuzzy sedang maka tingkat keanggotaan sesuai fungsi berikut:

Himpunan Fuzzy Pengalaman Melaksanakan Adat Setempat kurang (55) $=0,0$

Nilai 55 tidak termasuk dalam range Pengalaman Melaksanakan Adat Setempat kurang.

Himpunan Fuzzy Pengalaman Melaksanakan Adat Setempat Sedang (55) =60-55/ 60- $30=5 / 30=0,17$

Nilai 55 termasuk dalam range Pengalaman Melaksanakan Adat Setempat sedang, maka hasil yang didapat adalah 0,17 .

Himpunan Fuzzy Pengalaman Melaksanakan Adat Setempatbaik (55) = 80-55 / 80-50 =25/30 = 0,83

Nilai 55 termasuk dalam range Pengalaman Melaksanakan Adat Setempat baik, maka hasil yang didapat adalah 0,83 .

Variabel Sikap Masyarakat Terhadap Budaya Setempat telah didefinisikan pada tiga himpuan fuzzy, yaitu: kurang, sedang dan baik. Sikap Masyarakat Terhadap Budaya Setempat 30 termasuk kedalam himpunan fuzzy kurang dengan tingkat keanggotaan sesuai fungsi berikut:

Sikap Masyarakat Terhadap Budaya Setempat (30) $=35-30 / 35-10=5 / 25=0,2$

Nilai 30 termasuk dalam range Sikap Masyarakat Terhadap Budaya Setempat kurang.Sikap Masyarakat Terhadap Budaya Setempat sedang $(30)=55-30 / 55-30=1$

Nilai 30 termasuk dalam range Sikap Masyarakat Terhadap Budaya Setempat sedang, maka hasil yang didapat adalah 1 .

Sikap Masyarakat Terhadap Budaya Setempat baik (30) $=0,0$

Nilai 30 tidak termasuk dalam range Sikap Masyarakat Terhadap Budaya Setempat baik, maka hasil yang didapat adalah 0,0 .

Tahap dari proses perhitungan fuzzy berikutnya adalah tahapan penalaran.

Dalam proses penalaran ada 3 hal yang dilakukan yaitu mengaplikasi operatorfuzzy, metode implikasi dan komposisi. Dari tiga input fuzzy tersebut, kita akan menentukan rule - rule. Rule yang diperoleh ada 27 rule yang akan ditetapkan.Rule 1 :If (Pemahaman Adat Setempat kurang) and(Pengalaman Melaksanakan Adat Setempat kurang) and (Sikap Masyarakat Terhadap Budaya Setempat kurang) then (Persepsi Masyarakat kurang)

Rule 2 : If (Pemahaman Adat Setempat kurang) and (Pengalaman Melaksanakan Adat Setempat sedang) and (Sikap Masyarakat Terhadap Budaya Setempat kurang) then (Persepsi Masyarakat kurang), dst. 
Dari 27 rule yang ada, rule fuzzy yang akan ditampilkan hanya 5 aturan saja, yaitu ( Rule 4), (Rule 8), (Rule 9), (Rule 17) dan (Rule 18) sedang yang lainnya dapat dilihat pada halaman sebelumnya. Proses rule :

[ Rule 4] If (Pemahaman Adat Setempat is kurang) and (Pengalaman Melaksanakan Adat Setempat is sedang) and (Sikap Masyarakat Terhadap Budaya Setempat kurang) then (Persepsi Masyarakat Pendatang Terhadap Kearifan Lokal is kurang) .

Operator yang digunakan adalah AND, sehingga:

$\alpha 4=\min (\mu$ Pemahaman Adat Setempat [40], $\mu$ Pengalaman Melaksanakan Adat Setempat [55], $\mu$ Sikap Masyarakat Terhadap Budaya Setempat [30])

$=\min (0,33 ; 0,17 ; 0,2)$

$=0,17$.

[ Rule 8] If (Pemahaman Adat Setempat is kurang) and (Pengalaman Melaksanakan Adat Setempat is baik) and (Sikap Masyarakat Terhadap Budaya Setempat sedang) then (Persepsi Masyarakat Pendatang Terhadap Kearifan Lokal is kurang). Operator yang digunakan adalah AND, sehingga:

$\alpha 8=\min (\mu$ Pemahaman Adat Setempat [40], $\mu$ Pengalaman Melaksanakan Adat Setempat [55], $\mu$ Sikap Masyarakat Terhadap Budaya Setempat [30])

$=\min (0,3 ; 0,83 ; 1)$

$=0,3$

[ Rule 9] If (Pemahaman Adat Setempat is kurang) and (Pengalaman Melaksanakan Adat Setempat is baik) and (Sikap Masyarakat Terhadap Budaya Setempat baik) then (Persepsi Masyarakat Pendatang Terhadap Kearifan Lokal is sedang)

Operator yang digunakan adalah AND, sehingga:

$\alpha 9=\min (\mu$ Pemahaman Adat Setempat [40], $\mu$ Pengalaman Melaksanakan Adat Setempat [55], $\mu$ Sikap Masyarakat Terhadap Budaya Setempat [30])

$=\min (0,3 ; 0,83 ; 0,0)=0,0$

[ Rule 17] If (Pemahaman Adat Setempat is sedang) and (Pengalaman Melaksanakan Adat Setempat is baik) and (Sikap Masyarakat Terhadap Budaya Setempat sedang) then (Persepsi Masyarakat Pendatang Terhadap Kearifan Lokal is sedang)

Operator yang digunakan adalah AND, sehingga:

$\alpha 17=\min (\mu$ Pemahaman Adat Setempat [40], $\mu$ Pengalaman Melaksanakan Adat Setempat [55], $\mu$ Sikap Masyarakat Terhadap Budaya Setempat [30])

$=\min (1 ; 0,83 ; 1)$

$=0,83$

[ Rule 18] If (Pemahaman Adat Setempat is sedang) and (Pengalaman Melaksanakan Adat Setempat is baik) and (Sikap Masyarakat Terhadap Budaya Setempat baik) then (Persepsi Masyarakat Pendatang Terhadap Kearifan Lokal is sedang)

Operator yang digunakan adalah AND, sehingga:

$\alpha 18=\min (\mu$ Pemahaman Adat Setempat [40], $\mu$ Pengalaman Melaksanakan Adat Setempat [55], $\mu$ Sikap Masyarakat Terhadap Budaya Setempat [30])

$=\min (1 ; 0,83 ; 0,0)$

$=0,0$

Langkah terakhir dalam proses ini adalah defuzzifikasi atau disebut juga tahap penegasan.Metode yang digunakan adalah metode centroid. Berikut ini mengubah himpunan fuzzy menjadi bilangan real :

[Rule 4 ] Persepsi Masyarakat Pendatang Terhadap Kearifan Lokal (x) =0,17, maka nilai x adalah ; 
Persepsi Masyarakat Pendatang Terhadap Kearifan Lokal (kurang)

$=50-x / 20=0.17$

$=(50-(0,17 \times 20)$

$=46,6$

[Rule 8 ] Persepsi Masyarakat Pendatang Terhadap Kearifan Lokal (x) =0,3, maka nilai x adalah ;

Persepsi Masyarakat Pendatang Terhadap Kearifan Lokal (kurang)

$=50-x / 20=0.3$

$=(50-(0,3 \times 20)$

$=44$

[ Rule 17] $\mu$ Persepsi Masyarakat Pendatang Terhadap Kearifan Lokal Sedang (x) =0,383 maka nilai $\mathrm{x}$ adalah ;

Persepsi Masyarakat Pendatang Terhadap Kearifan Lokal $($ sedang $) \quad=(\mathrm{d}-10) / 40=0,83$

$$
\begin{aligned}
& =(0,83 \times 40)+10 \\
& =46,5
\end{aligned}
$$

[ Rule 18] $\mu$ Persepsi Masyarakat Pendatang Terhadap Kearifan Lokal sedang(x) =0,0maka nilai $\mathrm{x}$ adalah ;

Persepsi Masyarakat Pendatang Terhadap Kearifan Lokal $($ kurang $)=(\mathrm{d}-40) / 10=0,3$

$$
\begin{aligned}
& =(0,0 \times 40)+10 \\
& =10
\end{aligned}
$$

Maka, dengan menggunakan metode defuzzy weighted average diperoleh Persepsi Masyarakat Pendatang Terhadap Kearifan Lokal adalah:

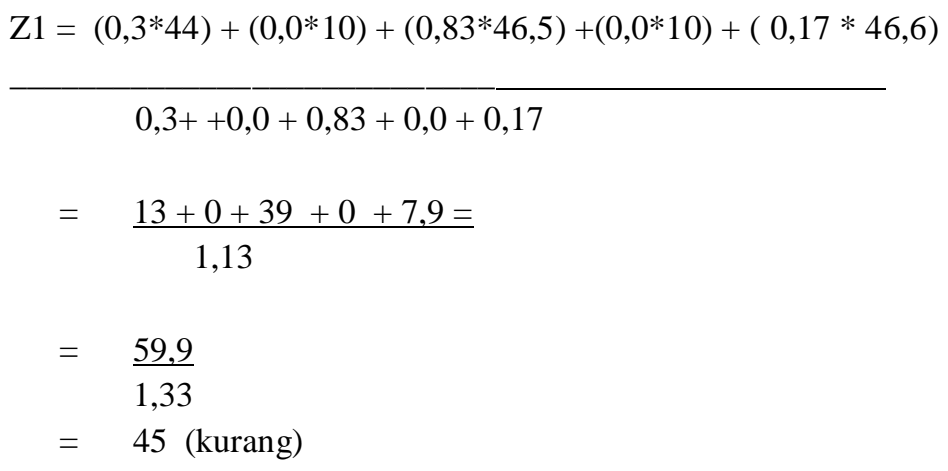

Dari hasil perhitungan data di atas diperoleh nilai defuzzifikasi $\mathrm{Z}_{1}=\mathbf{4 5}$. Jadi, dari hasil yang diperoleh output berada pada range $\mathbf{1 0} \leq \boldsymbol{X} \leq \mathbf{5 0}$ yaitu kurang. Maka dinyatakan bahwa atas nama Nimar tersebut.

Persepsi Terhadap Kearifan Lokal nya yaitu kurang baik.

Variabel sikap masyarakat terhadap budaya setempat dengan nilai range [10 - 75] dan setiap variabel kurang, sedang dan baik masing-masing memiliki nilai yang berbeda pada gambar 4 . 


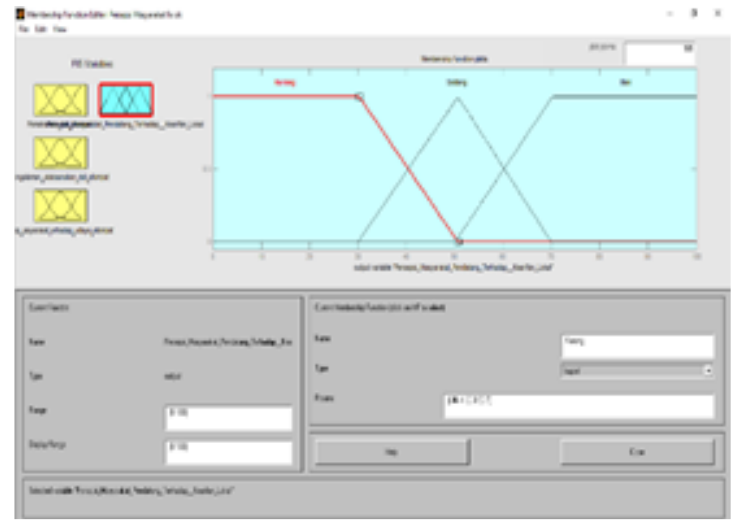

Gambar 4.Membership Function Persepsi Masyarakat pendatang terhadap Kearifan Lokal.

Selanjutnya menentukan aturan fuzzy yang akan digunakan yang dihitung berdasarkan ketentuan jumlah himpunan masing-masing variabel input. Tampilan kotak dialog rule editor dari model sistem analisa menetukan persepsi masyarakat yang dirancang pada gambar 5 .

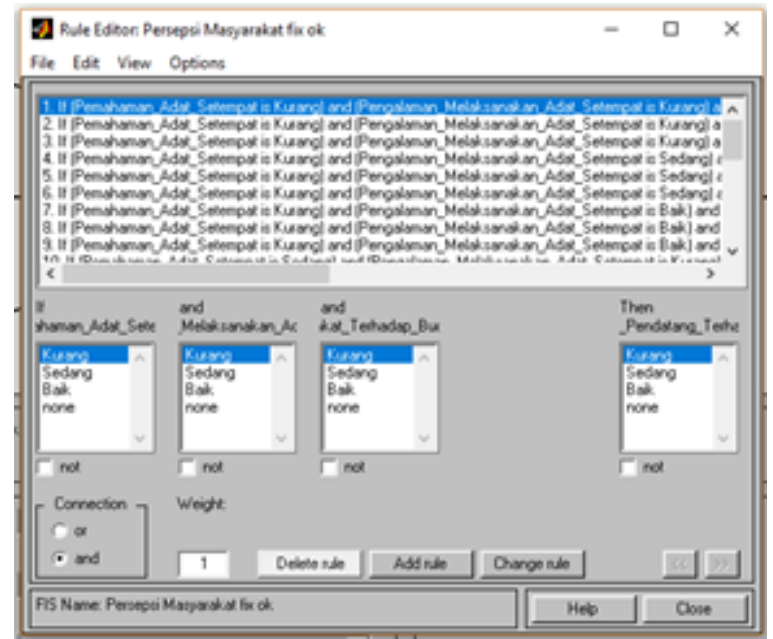

Gambar 5.Rule Editor dari Variabel FIS Persepsi Masyarakat Pendatang terhadap Kearifan Lokal

Langkah selanjutnya adalah pengujian sistem.Pada tahap pengujian ini sudah dilakukan pengambilan sampel data.Rule yang diperoleh pada penelitian ini ada 27 rule yang akan ditetapkan berdasarkan input dan output pad agambar 6.

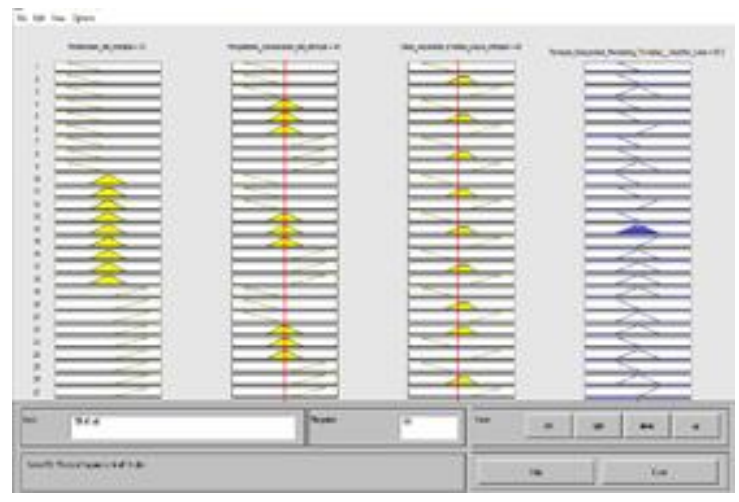

Gambar 6.Rule Viewer dari Variabel FIS Persepsi Masyarakat Pendatang terhadap Kearifan Lokal.

Tampilan akhir dari aplikasi Matlab pada FIS editor ini adalah Surface Viewer pada gamabr 7. 


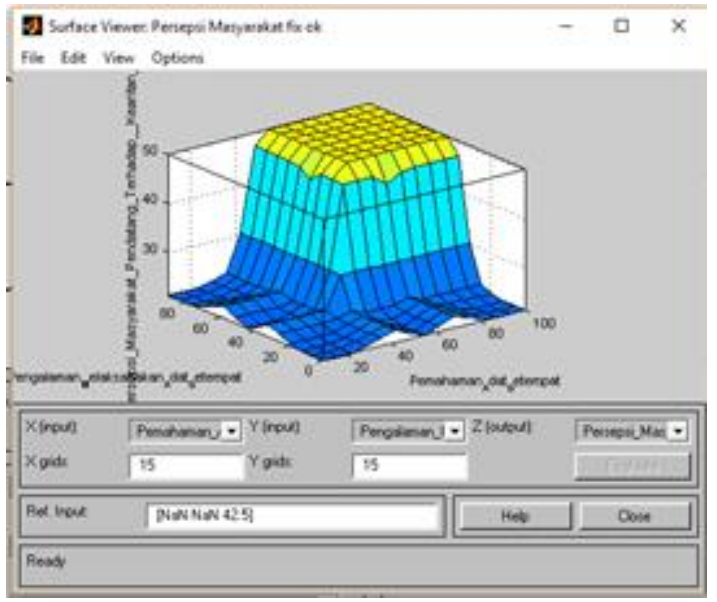

Gambar 7.Surface Viewer FIS Persepsi Masyarakat Pendatang terhadap Kearifan Lokal

\section{Kesimpulan}

Dengan adanya penentuan persepsi masyarakat pendatang terhadap kearifan local dengan beberapa aspek dari pemahaman adat setempat dari pengujian dengan fuzzy dan Marlab pengalaman melaksanakan adat setempat dan sikap masyarakat terhadap budaya setempat masyarakat dapat mengetahui, mempelajari serta mampu mengkaji strategi penduduk pribumi dan pendatang dalam membatasi konflik.

\section{Referensi}

[1]. Asih, M. S. (2018). Sistem Pendukung Keputusan Fuzzy Mamdani pada Alat Penyiraman Tanaman Otomatis. Query: Journal of Information Systems, 2(1).

[2]. Suwintana, I. K. (2013). Sistem Inferensi Fuzzy Mamdani Berbasis Web. Jurnal Matrix, 3(1).

[3]. Buana, W. (2017). Penerapan Fuzzy Mamdani Untuk Sistem Pendukung Keputusan Pemilihan Telepon Seluler. Edik Informatika, 2(1), 138-143.

[4]. Akhirina, T. Y., \& Sonny, M. (2017). Fuzzy Inference System (FIS) dengan Metode Tsukamoto dan Mamdani dalam Menentukan Kelayakan Kenaikan Gaji Karyawan. Jurnal Komtika, 1(2), 7-14.

[5]. Gani, E., Kolibu, H. S., \& Tamuntuan, G. H. (2016). Pemanfaatan Logika Fuzzy Untuk Sistem Prediksi Banjir. Jurnal MIPA, 5(2), 81-84.

[6]. Hidayah, E. N., Utami, Y. R. W., \& Saptomo, W. L. Y. (2016). Analisis Algoritma Fuzzy Inference System (Fis) Mamdani Pada Sistem Pendukung Keputusan Penjurusan Siswa Di Sma Negeri 1 Jatisrono. Jurnal Teknologi Informasi dan Komunikasi (TIKomSiN), 4(2).

[7]. Jurnal, R. T. (2017). Implementasi Logika Fuzzy Untuk Sistem Otomatisasi Pengaturan Pengisian Batere Pembangkit Listrik Tenaga Surya. ENERGI \& KELISTRIKAN, 9(2), 111 119.

[8]. Pratiwi, M., \& Kartika, D. (2016). Sistem Informasi Pengelolaan Kegiatan Simpan Pinjam Koperasi Pegawai Republik Indonesia (Kpri). MAJALAH ILMIAH UPI YPTK, 23(1).

[9]. Rahakbauw, D. L., Rianekuay, F. J., \& Lesnussa, Y. A. PENERAPAN METODE FUZZY MAMDANI UNTUK MEMPREDIKSI JUMLAH PRODUKSI KARET (STUDI KASUS: DATA PERSEDIAAN DAN PERMINTAAN PRODUKSI KARET PADA PTP NUSANTARA XIV (PERSERO) KEBUN AWAYA, TELUK ELPAPUTIH, MALUKU- 
INDONESIA). JURNAL ILMIAH MATEMATIKA DAN TERAPAN, 16(1), 51-59.

[10]. Marwoto, S. (2010). Pemodelan logika fuzzy terhadap kerusakan Jembatan Beton. Media Teknik Sipil, 10(1), 28-35.

[11]. Fiano, D. S. I., \& Purnomo, A. S. (2017). Sistem Pakar Untuk Mendeteksi Tingkat Resiko Penyakit Jantung Dengan Fuzzy Inferensi (Mamdani). Informatics Journal, 2(2), 64-78.

[12]. Wirawan, A., \& Azhari, A. (2013). Implementasi Metode Fuzzy-Mamdani untuk Menentukan Jenis Ikan Konsumsi Air Tawar Berdasarkan Karakteristik Lahan Budidaya Perikanan. BIMIPA, 24(1), 29-38.

[13]. Sitepu, E. (2018). Aplikasi Logika Fuzzy Menggunakan Metode Fuzzy Mamdani dalam Menentukan Jumlah Produksi Optimum Keripik Singkong (Studi Kasus: UD. Kreasi Lutvi). 